International Journal of Engineering \& Technology, $7(2.29)(2018) 219-225$
International Journal of Engineering \& Technology
Website: $w$ ww.sciencepubco.com/index.php/IJET
Research paper

\title{
Improving Quality Control Process Through Value Stream Mapping
}

\author{
Zulfa Fitri Ikatrinasari' ${ }^{1}$, Dan Kosasih ${ }^{2}$ \\ ${ }^{1}$ Industrial Enginering, Universitas Mercu Buana, Indonesia \\ ${ }^{2}$ Management, Universitas Mercu Buana, Indonesia
}

\begin{abstract}
PT. AEMI is one of the growing electronic component manufacturing company. By this time, Kaizen project has been run and managed to become a culture in PT AEMI. However, the project has not integrated, comprehensive and not yet has a long-term goals. Implementation of value stream mapping (VSM) in PT AEMI is expected to make Kaizen projects more focused and to produce increasing of the maximum efficiency. In addition, VSM Kaizen is believed to make the those programs more integrated, effective and comprehensive. This study aims to: (1) create a current state mapping in the Department of Quality Control PT. AEMI, (2) identify wastes in the Department of Quality Control PT.AEMI, (3) create a future state mapping at the Department of Quality Control PT. AEMI, (4) make a plan of improvement and analyzing the application. Stages of the study were as follows: (1) identification of work processes, (2) collect and analysis of work process time, (3) analysis of the current state mapping, (4) calculate of lead time and process time, (5) analysis of value added and non value-added activities, (6) analysis of wastes, (7) make a plan of future state mapping, (8) improvement design (improvement planning), (9) implementation of improvement, (10) analysis of the implementation of improvements. The results of this study are: 1) current state mapping at QC Department shows that the total lead time of 848 minutes where there is non-value added activity of 778 minutes. 2) identify waste on the handling process where the product movement from assembly to QC for 2 minutes, movement transactions from assembly to QC for 479 minutes and the waiting time at inspection area for 727 minutes. 3) future state mapping at QC Department shows that the total lead time of 516.5 minutes where there is non-value added activity of 446.5 minutes. 4) the improvement to do is to change the lay out where final inspection is moved from QC to manufacturing so as to result in reduce of non-value added activity by $46 \%$.
\end{abstract}

Keywords: lean manufacturing; value stream mapping; electronic component manufacture.

\section{Introduction}

Economic globalization has brought a new, very fast and broad influence on the economy. The speed of globalization had an impact on increasing competition in the industrial sector due to the open the local market as well as from and to foreign countries. The products of local industry should also be able to compete with overseas products that enter the domestic market. Companies must be able to improve and optimize all the potential ability to compete in globalization era. It can be improved by the increasing of value added and productivity's rate along the production chain. Each company is required to apply the strategy that can support performance in improving the effectiveness and efficiency of their business operations. The strategy should be able to help achieve the company objectives in the long term in order to growth and thrive on.

In 2012, Indonesia's manufacturing industry has achieved considerable growth in the amount of $6.40 \%$ and has greatly contributes in the export up to $60.02 \%$ of the total national exports. The amount of growth in the manufacturing industry is certainly consistent with the increasingly large market penetration. The increasing of demand will have an impact on increasing production capacity of companies in this industry. The efficiency of the process, the effective of delivery and the quality of product is the initial succes factors for the industry.
Value Stream Mapping (VSM) is a visual way to describe the flow of material and information on the production process of a product. VSM can also be used to identify non-value added activities that occur during the production process1. VSM is one of many tools in a lean manufacturing concept. Two tools are commonly used in the lean concept is value stream mapping and kaizen rapid process improvement events.

Lean manufacturing is the principles and methods that focus on the systematic identification and elimination of non-value added activities (waste) that is involved in producing a product or providing service to customers (Womack et al., 1990). Lean manufacturing is believed to support implementing the company's strategy more effectively. According to Carroll 2, Lean is a philosophy and practical ways to eliminate all waste in all production processes continuously. By applying lean principles in practice can successfully improve the production process continuously. The concept of lean manufacturing is applied based on the real conditions in identifying problems and waste (non-value added).

PT. AEMI is one of the electronic component manufacturing industry is growing. One Mission PT AEMI is increased efficiency. The efficiency of the production process can be improved through kaizen, or continuous improvement projects. During this time kaizen projects have been run and managed to become a culture in PT AEMI. However, these projects have not been integrated and comprehensive and yet have long-term goals. Application of value 
stream mapping in PT AEMI is expected to steer the projects Kaizen resulted in maximizing efficiencies .

Department of Quality Control (QC) is the most important departments at PT AEMI in creating business process efficiency. This is because the QC department deals with all departments in PT AMI, such as warehouse department, stamping department, molding department and assembling department. Therefore in this study will be focused on the QC department to be a pilot project and is expected to serve as an example and guidance for other departments in PT AEMI to apply VSM.

Based on the background described above, we formulated the research objectives are:

1) creating a mapping current state in the Department of Quality Control PT. AEMI

2) identifying waste in the Department of Quality Control PT.AEMI,

3) creating a future state mapping at the Department of Quality Control PT. AEMI and 4) making an improvement plan and it's analysis.

\section{Literature Review}

\subsection{Lean manufacturing}

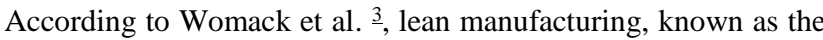
Toyota Production System, developed by Toyota Motor Company is based on the principles of Henry Ford. Lean refers to the principles and methods that focus on the systematic identification and elimination of non-value added activities (waste) that is involved in producing a product or providing service to customers. Two methods are commonly used in lean are value stream mapping and kaizen to accelerate process improvement events.

According to Carroll (2008), Lean Production is a philosophy and practical ways to eliminate all waste in all production processes continuously. By applying lean principles in practice can successfully improve the production process on an ongoing basis.

Lean techniques to identify and eliminate unnecessary activities (non-value) and continuously improvement activities from time to time. It is also known as Kaizen, is another key concept in the implementation of lean service. In addition to eliminating waste, lean service encourages employees to continually look for ways to innovate and improve the added value. Kaizen philosophy has changed approach method from top-down to bottom-up method. Kaizen creates continuous improvement from simple ideas come from employees, instead of the results of research and development.

According to Womack et al. $\frac{3}{3}$, the term lean for the first time in the automotive industry. Lean can be interpreted as "slim". This corresponds to the concept of lean that desire a just process contains activities that need and have added value. While activities that do not need / no value added is defined as waste or waste, and must be eliminated. Lean focus on value-added, it can be achieved through constant evaluation of the improvement process. Lean Production developed at Toyota have totally revolutionized the way we produce in many kinds of manufacturing industries in all corners of the world and has shown remarkable results.

Although lean success story has been proven in manufacturing industry, but there are still some challenges in the implementation of lean processes. Worley \& Doolen ${ }^{4}$, giving special attention to the readiness of employees to accept the concept of lean. It is very difficult to ask employees to change their way of thinking in an attempt to focus on the values desired by the customer and identify waste. For example, the concept of the Just In Time delivery of goods in small quantities and are often considered to be troublesome than once delivery in large numbers. More over, the difficulties in identifying the process in the field of services industry is, the absence of physical evidence, specially when it compared with manufacturing industry.

According to Sarkar $\stackrel{5}{5}$, the full support of management is very influential in the successful implementation of lean. If workers feel management does not respect their efforts, they reluctance to continue the lean concept, which will ultimately frustrate the implementation of lean ${ }^{4}$. Communication becomes an important key in the implementation of lean. With clear communication among departments, the purpose and the implementation of lean process shall be understood by everyone.

\subsection{Five Principles of Lean}

According to Chauhan ${ }^{6}$ Lean manufacturing and lean enterprise means that a company focusing on what is desired by the customer, purchased products are not defective and just in time delivery. Those principles can be explained as follows:

1. Customer Value, a value that must be added in order to meet customer desire.

2. Value Stream, the flow of material and information. To be able to calculate non-value added activities, we must make the flow of a product or service from the beginning until accepted by the customer. A customer does not want to pay the activity or the production process of manufacturing that do not generate value.

3. Continuous Flow, no bottlenecks, rework, just flow. How to create a flow of product or service that involves a series of activities that are value-added and replace the batch and queue system in a continuous flow

4. Pull Process - everything should be pulled from the customer. Creating mechanisms pull system by making what customers demand and when they need

5. Continuous Improvement or Perfection - strive towards it everyday. This will be done by continuous improvement.

\subsection{Seven Waste}

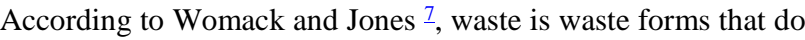
not have added value and tend to harm as well as in the manufacturing industry, which can hamper operations and hurt the company. Waste that occurs in the field of service to the fading tails of loyalty, loss of customer confidence, reduced profits, and affect the corporate image in the public's eye directly. Here are the Seven Wastes that often occurs in the service-based business, as seen from the customer's perspective. 7 waste include:

1. Transport (it consists of a transfer or conveyance that is not necessary as the temporary placement, stacking back, the movement of goods)

2. Excess Inventory (Inventory, stock or excess inventory)

3. Movement (in the form of time spent on searching, inefficient movement and not ergonomics)

4. Waiting (it includes oversee activity of automatic machine, waiting for incoming stuff, etc.)

5. Over Production (produces products exceeds demand, or ahead of schedule)

6. Over Processing (adding that the process is not required for goods products will only add to the cost of production

7. Rework (rework no value added that the customer does not want to pay). 
Womack and Jones $\underline{7}$ defines eight types of light, namely: defects or rework, overproduction, inventory waiting to be processed, unneeded processing, unnecessary movement of people, unnecessary transport of goods, people waiting for input to work on and design of goods and services that do not satisfy customer needs

\subsection{Value Stream Mapping}

Value Stream Mapping is a visual way to describe the flow of material and information in the process of production of the product. VSM can also be used to identify non-value added activities that occur during the production process. In the field of administrative/office, Value Stream are all steps, both value added and nonvalue added, which is conditional on completing a service from beginning to end.

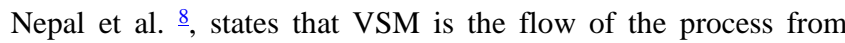
beginning to end in providing the desired results, service, or "value stream" product which expected by customers. VSM checking the flow of information and systems, as well as the flow of the product or service (eg permits) through an agency. VSM can improve the understanding of the actual decision-making process and identify the sources of time of non-value added time (for example, documents waiting for review). VSM identified two maps, namely "current state" map process and the "future state" map of the desired process flow and implementation plans related to process improvement activities in the future.

According to Gill $\stackrel{9}{-}$, mapping process steps are as follows:

1. Identify a product or service family;

2. Create current value stream to determine the current problem from the point of view of the organization and the customer;

3. Create an ideal future state map.

4. Identify corrective actions needed to close the gap between the current state and the ideal future state.

5. Implement the corrective actions.

6. Create a new current state map to verify if the problems identified in step 2 has been eliminated/mitigated.

\subsection{Current state Map}

Stages of current state mapping areas follows:

1. Determination of the product family that to be the model line. The purpose of mode-line is that the systems are focused on a single product that can be considered as a reference and the representation of the existing production system.

2. Making maps for each category of process (door-to-door flow) along the value stream. At this stage, detailed observations for each category of the process. For each process, all critical information including lead time, cycle time, uptime, number of operators and working time (already reduced by time off), inventory levels, and others need to be documented. All of which will be included in the data box for each process. For each box data generation, the necessary measures, among others: a. Cycle time $(\mathrm{C} / \mathrm{T})$

Time required by an operator to complete all activities in making one part before repeating activities to make the next part.

b. Uptime

Machine capacity used in working on a process.

c. Number of operator

Number of operators required in performing a process.
The final step in the VSM is to create a future state map. The purpose of VSM is to clearly identify sources of waste and help create target areas for improvement processes. Hence, future state map is the implementing a plan that describes what tools are required in lean processes to eliminate waste and at what process it is necessary. Guidelines for the preparation of future state map are as follows:

1. Developing a continuous flow (continuous flow) where ever possible. Continuous flow refers to producing one piece at a time, with each item passed immediately form one process step to the next without stagnation (and many other wastes) in between.

2. Use supermarkets to control the continuous flow of current production (continuous flow) was not until the upstream stage.

Sometimes some areas in the value stream where continuous flow is impossible to implement while grouping is required. There are several reasons that can cause this, namely:

1. Some of the processes that are designed to operate in a very fast cycle time or even very slow and need change over to serve the product family simultaneously.

2. Some processes, such as the process in suppliers located in a remote location, therefore the delivery of the product at one time becomes unrealistic.

3. Some processes have too much lead time or it is not possible to directly combine one process with another process in a continuous flow.

Production control often through supermarkets pull-based systems. Pull-systems usually need to be placed in areas that continuous flow is interrupted and an upstream processes that are yet to be applied in one batch sizes. The objectives of positioning a pull-system between two processes are as a means of providing accurate production instructions for upstream process, so it is not necessary to predict downstream demand and schedule upstream process. Pull-system is a production control method among the flow. Supermarket sign is open on the left side, facing the delivery process by supplier. This is because the supermarket is part of the supply process and used in the scheduling process.

\subsection{Previous Research Review}

Previous researches in the implementation of VSM are as in Table 1. Below

Table 1: Previous Reserach

\begin{tabular}{|c|c|c|}
\hline No & $\begin{array}{l}\text { Journal Title (Authors, } \\
\text { Year) }\end{array}$ & Result \\
\hline 1 & $\begin{array}{l}\text { Study on streamlined process } \\
\text { improvement by using Value } \\
\text { Stream Mapping in automotive } \\
\text { Seating company: a case study } \\
\text { (Puvanasvaran } \text { et al., 2013) }\end{array}$ & $\begin{array}{l}\text { Through the VSM team identi- } \\
\text { fying bottlenecks and making } \\
\text { improvements plan, the result } \\
\text { of the formulation of } 4 \text { poten- } \\
\text { tial improvements which then } \\
\text { created a new relayout more } \\
\text { efficient }\end{array}$ \\
\hline 2 & $\begin{array}{l}\text { Value Stream Mapping: A } \\
\text { Case Study Of Automotive } \\
\text { Industry (Palak et al., 2014) }\end{array}$ & $\begin{array}{l}\text { Case study on Lean Corpora- } \\
\text { tion Halol uses VSM to identify } \\
\text { waste. Reduction of non value } \\
\text { added activities by } 25.6 \% \text { and } \\
\text { reduction of lead time by } \\
66.7 \%\end{array}$ \\
\hline 3 & $\begin{array}{l}\text { Enhancing Lean manufactur- } \\
\text { ing Using The Value Stream } \\
\text { Mapping Tool in Pharmaceu- } \\
\text { tical Operations : A Case } \\
\text { Study of A Pharmaceutical } \\
\text { Manufacturing Company in } \\
\text { Zimbabwe. (Goriwondo et al., } \\
\text { 2013) }\end{array}$ & $\begin{array}{l}\text { - Useful for a variety of in- } \\
\text { dustry sectors } \\
\text { - Implementation on the } \\
\text { pharmaceutical industry not- } \\
\text { ed success } \\
\text { - The VSM application en- } \\
\text { sures the approach is system- } \\
\text { atic and brings significant } \\
\text { changes to the product }\end{array}$ \\
\hline
\end{tabular}




\begin{tabular}{|c|c|c|}
\hline 4 & $\begin{array}{l}\text { Quality Initiatives: Lean Ap- } \\
\text { proach to Improving Perfor- } \\
\text { mance and Efficiency in a } \\
\text { Radiology Department (Jona- } \\
\text { than et al., 2012) }\end{array}$ & $\begin{array}{l}\text { The tools used in this study } \\
\text { are: Value Stream Mapping, to } \\
\text { visualize the state of the cur- } \\
\text { rent process and identify ac- } \\
\text { tivities that do not provide } \\
\text { added value; Root cause analy- } \\
\text { sis to determine the underlying } \\
\text { cause of a problem }\end{array}$ \\
\hline 5 & $\begin{array}{l}\text { Identification of Waste } \\
\text { Through Value Stream Map- } \\
\text { ping (VSM) on Job Training } \\
\text { for Lean Service (Ikatrinasari, } \\
\text { 2015) }\end{array}$ & $\begin{array}{l}\text { Based on the research that has } \\
\text { been done, it can be seen that } \\
\text { the waste that occurs in the } \\
\text { process of IT Practice Work is } \\
\text { delays or waiting, duplication } \\
\text { or overproduction, error / de- } \\
\text { fect environmental and lost } \\
\text { opportunity. Based on VSM, it } \\
\text { can be known that the current } \\
\text { Lead Time KP is } 1159.75 \\
\text { hours with the activity time of } \\
\text { Value Added } 79.75 \text { hours and } \\
\text { Non Value Added } 1080 \text { hours.. }\end{array}$ \\
\hline 6 & $\begin{array}{l}\text { Implementation of Lean Ser- } \\
\text { vice with Value Stream Map- } \\
\text { ping at Directorate Airworthi- } \\
\text { ness and Aircraft Operation, } \\
\text { Ministry of Transportation } \\
\text { Republic of Indonesia (Ikatri- } \\
\text { nasari \& Haryanto, 2014) }\end{array}$ & $\begin{array}{l}\text { The reduction of total lead } \\
\text { time, makes total cycle time } \\
\text { decrease significantly, i.e. } \\
69 \% \text {, or from } 94.5 \text { to } 29.5 \\
\text { days, while the process time is } \\
\text { constant, i.e. } 18 \text { days. Future } \\
\text { state mapping can reduce lead } \\
\text { time and increase cycle time } \\
\text { efficiency. Current State Map- } \\
\text { ping shows weaknesses/waste } \\
\text { and is non value added. Cur- } \\
\text { rent state shows quite a high } \\
\text { lead time value, so that cycle } \\
\text { time efficiency is low. The } \\
\text { efficiency value is } 0.112 \text { and } \\
\text { after future state mapping } \\
\text { becomes } 0.70 \text {. }\end{array}$ \\
\hline 7 & $\begin{array}{l}\text { Perbaikan Sistem Produksi } \\
\text { Minyak Angin Aromatherapy } \\
\text { melalui Lean manufacturing di } \\
\text { PT.US Jawa Barat } \\
\text { (Purnama \& Ikatrinasari, } \\
\text { 2013) }\end{array}$ & $\begin{array}{l}\text { This study aims to improve } \\
\text { productivity by identifying and } \\
\text { balancing the work process and } \\
\text { investigate the cause of the } \\
\text { length of cycle time through } \\
\text { value stream mapping. This } \\
\text { research resulted in a decrease } \\
\text { in cycle time of } 538.96 \text { sec- } \\
\text { onds to } 445.68 \text { seconds, de- } \\
\text { creasing personnel } 14 \text { people, } \\
\text { reduction of operational costs } \\
\text { man power Rp. } 18,2 \text { million per } \\
\text { month, and reduce lead time } \\
\text { from } 14.5 \text { days to } 11.5 \text { days. }\end{array}$ \\
\hline
\end{tabular}

\section{Methodology}

\subsection{Subjects and Research Objects}

This research has been conducted at PT. AEMI located at Marunda Industrial Estate, near from capital city of Jakarta. Field of business of PT. AEMI is manufacturing of connectors for consumer electronic equipment, $\mathrm{OA}$ and communication equipment, FA equipment and automobiles, solderless terminals and chain terminals. The number of workers is 212 people with 79 men and 133 women.

\subsection{Research Stages}

Stages of this research are as follows:

1. Identification of Work Process

The applicable work processes will be identified and arranged in the order of work. Based on the work process will be made current stream mapping. The new work process will be developed based on future state mapping.

2 Work Process Time Collection and Analysis

The time data of each process will be calculated and analyzed to determine the average time. This average time will be placed as the lead time and process time in Value Stream Mapping to be created.

3. Current State mapping analysis

All job steps are collected and analyzed, job steps include value added and non-value added. These steps are required for the company to complete the service from start to finish. The data is processed to make the current state mapping and fix it into an ideal future state mapping.

4. Calculation of Lead Time and Process Time

After the current State mapping is created, calculations and lead time analysis are calculated the process speed, how long the time required for service permissions after the application occurs. Lead time using simple equations of Little Law:

Lead Time $=\underline{\text { Amount of Work-In-Process }}$

Average Completion Rate

Work in process begins by calculating how many permissions or application updates should be received in a day, week, month and so on (average completion rate). If the average completion of work and WIP is known, then it can be estimated how much its lead time. By calculating the lead time and completion rate, we will know the WIP (work in process). Process cycle efficiency (PCE) is related to the value or the sum of value-add time divided by the total lead time of the process:

$$
\text { Process Cycle Efficiency } \quad=\frac{\text { Value }- \text { add Time }}{\text { Total Lead Time }}
$$

\section{Value Added and Non-Value Added Analysis}

From the process of mapping that has been made will be calculated how the value of each time and divided into groups of activities. According to Hines and Rich (1997), there are 3 (three) types of operating groups taken:

A. Non-value adding (NVA);

B. Necessary but non-value adding (NNVA); And

C. Value-adding (VA).

\section{Waste Analysis}

At this stage, the identification and analysis of waste or non-value added will be done with 2 (two) approaches, namely:

A. Direct observation in the work environment or the identification of seven waste and eight young types can be done before the current state mapping is made. Waste will be recorded during the collection, processing and analysis of research data.

B. Waste or non-value identification is added after the current state mapping is made. Waste or non-value added will be identified in each work process.

7. Future State mapping planning.

Future mapping planning will be done after the whole picture of how the work process both from the side of the movement of the letter and time information in current state mapping obtained. In other words, future state mapping is the result of analysis of weakness of current state mapping. With the very detailed data about demand, iventory, schedule, cycletime. Then can see a problem that can be an opportunity to make improvements.

8. Improvement planning (Improvement planning)

The design stage of the improvement is to determine the action plan to bring about the necessary improvements to achieve future circumstances. This action plan should include priorities for different developments, actions related to people, clear timelines, and sponsorship involvement.

9. Implementation of improvements

Any change must cause "discomfort". Discomfort is not only because you have to start getting new things lean, but also demanding to be consistent and not tempted to go back to old habits. Here the role of a leader who is a role model, and inspiration to always be together with his team to build commitment and consistently run new process activities to create lean environment.

10. Analysis of improvement implementation

Implementation of the improvement is analyzed and monitored to start from the initial step again, which is to build a new current state mapping. 


\section{Results and Discussion}

\section{PT.AEMI's Overview}

PT. AEMI established since year of 2012, located in Bekasi industrial estate, near the city capital of Jakarta, Indonesia. The business fields is manufacturing of electronic components. The number of workers is 212 people with 79 men and 133 women. Quality policy at PT AEMI is committed to running quality activities by taking into account humanitarian values and generating new values for the improvement of people's welfare, through:

1. Comply with all established rules, meet customer requirements and make continuous improvement based on the ISO 9001 Quality Management System;

2. Conducting business activities by determining quality objectives and meeting all requirements and improving quality appropriately;

3. Periodically review the quality management system and quality objectives by internal auditors and by other management committees;

4. Quality policy must be submitted and understood by all employees, for example by holding QC Conference, morning meeting, information board and others.

The QC department is responsible for the inspection process of finished products from the assembling, molding and stamping department. The inspection is performed by QC department trough two types of inspection process, namely (1) $100 \%$ inspection process and (2) final inspection process. A 100\% inspection process is the process of inspecting all finished products in a fast way, while the final inspection process is conducted by sampling. In case of the inspection process has found a reject product, then it returned to the department concerned.

\section{Current State Mapping}

Current State Maping QC department can be seen in Figure 1. below. The flow of the QC department process is: 1) Product from manufacturing (molding, stamping and assembling), 2) Transfer of product from product to area before inspection, 3) Receipt by QC department by scan process, 4) Removal of product from 'before inspection' area to inspection table, 5) Conduct $100 \%$ inspection, 6) Transfer of product to "before final inspection', 7) Conduct final inspection in QC area (sampling, microscope and measurement) 8 ) Product transfer to packaging area, 9) Packaging

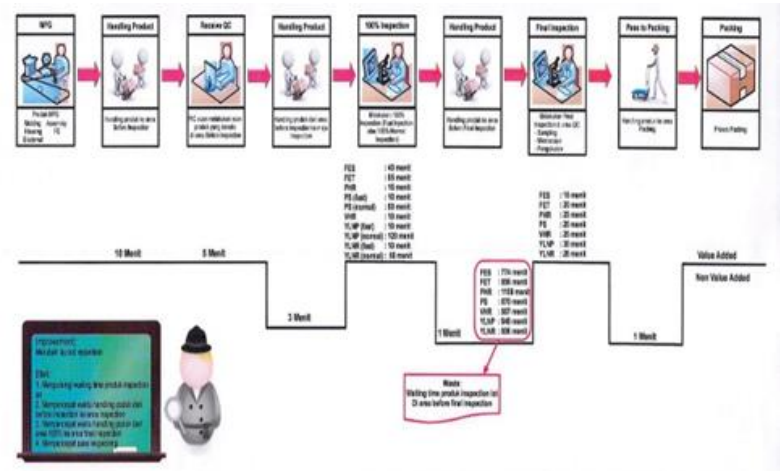

Gambar 1. Current State Mapping QC Dept

The $100 \%$ inspection process time data and final inspection for each product can be seen in Table 2. below.
Tabel 2. QC process time Dept. (Minutes) at this time

\begin{tabular}{|l|c|c|c|}
\hline Produk & $100 \%$ Inspection & $\begin{array}{c}\text { Pemindahan } \\
\text { produk }\end{array}$ & $\begin{array}{c}\text { Final } \\
\text { Inspection }\end{array}$ \\
\hline FES & 40 & 774 & 15 \\
\hline FET & 55 & 856 & 20 \\
\hline PHR & 15 & 1106 & 25 \\
\hline PS & 10 (fast) 50 (normal) & 870 & 20 \\
\hline VHR & 10 & 567 & 25 \\
\hline YLNP & 10 (fast) 120 (normal) & 848 & 30 \\
\hline YLNR & 10 (fast) 50 (normal) & 506 & 28 \\
\hline
\end{tabular}

\section{Value added dan non value added analysis}

Based on the above data can be known there is non value added activity on product handling from $100 \%$ inspection process to final inspection. Non value added consist of a waiting time in the final inspection process. Improvement that can be done is to change the lay out of inspection. Some of the benefits expected by changing lay out are as follows:

1. Reduce waiting time of inspection lot product

2. Accelerate the product handling time from 'before inspection' to 'inspection area'

3. Accelerate product handling time from ' $100 \%$ area' to 'inspection area'

4. Accelerate product transfer to packing area

\section{Future State Mapping}

Based on the analysis of non value added activities that have been described in the previous sub chapter, then made the future state mapping QC department in the future state which lead time reduction is obtained.

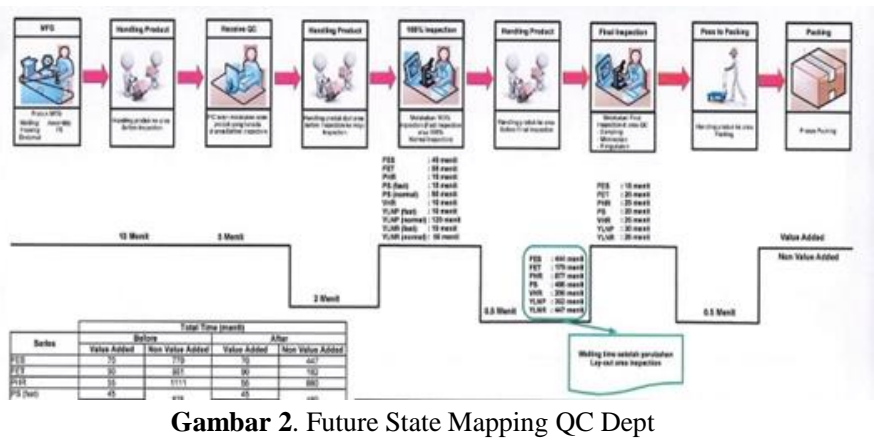

Future data for the $100 \%$ inspection process and final inspection for each product can be seen in Table 3. below.

\begin{tabular}{|l|c|c|c|}
\hline Produk & $100 \%$ Inspection & $\begin{array}{c}\text { Pemindahan } \\
\text { produk }\end{array}$ & $\begin{array}{c}\text { Final } \\
\text { Inspection }\end{array}$ \\
\hline FES & 40 & 444 & 15 \\
\hline FET & 55 & 179 & 20 \\
\hline PHR & 15 & 877 & 25 \\
\hline PS & 10 (fast) 50 (normal) & 486 & 20 \\
\hline VHR & 10 & 353 & 25 \\
\hline YLNP & 10 (fast) 120(normal) & 848 & 30 \\
\hline YLNR & 10 (fast) 50(normal) & 447 & 28 \\
\hline
\end{tabular}

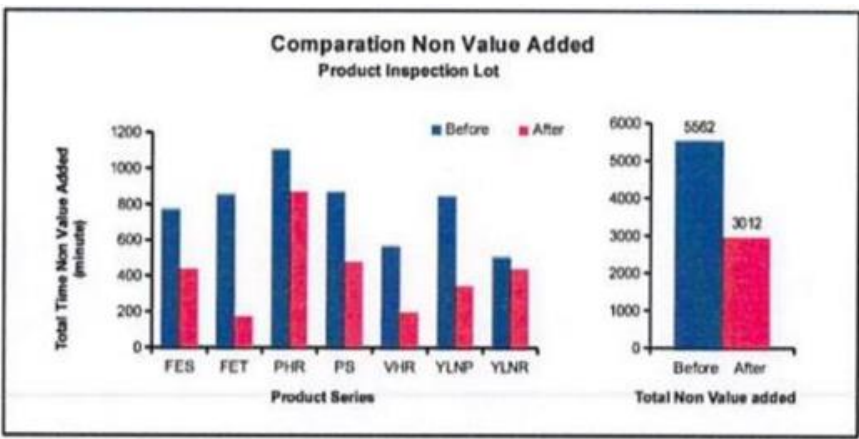

Fig 3. Comparison of non value added activity on current state and future state 
In Figure 3. and Table 4. it can be seen that the activity not worth adding at this time is 5562 minutes and the future is 3012 minutes or reduced to 2550 minutes $(46.8 \%)$.

Tabel 4. The time for non value added activity pada proses handling product

\begin{tabular}{|c|c|c|c|c|}
\hline \multirow{3}{*}{ Series } & \multicolumn{4}{|c|}{ Total Timo (monit) } \\
\hline & \multicolumn{2}{|c|}{ Before } & \multicolumn{2}{|c|}{ After } \\
\hline & Value Added & Non Value Added & Value Added & Non Value Added \\
\hline FES & 70 & 779 & 70 & 447 \\
\hline FET & 90 & 861 & 90 & 182 \\
\hline PHR & 55 & 1111 & 55 & 880 \\
\hline PS (tast) & 45 & & 45 & \\
\hline PS (100\% normal) & 85 & 875 & 85 & 489 \\
\hline MHR & 50 & 572 & 50 & 208 \\
\hline YLNP (tast) & 55 & & 55 & \\
\hline YLNP (100\% norma) & 165 & 853 & 165 & 356 \\
\hline YLNR (tast) & 53 & & 53 & \\
\hline YLNR ( $100 \%$ norma) & 93 & 511 & 93 & 450 \\
\hline Total & 761 & 5562 & 761 & 3012 \\
\hline
\end{tabular}

\section{Improvement}

Improvements that have been made to reduce non value added activity in the process of product handling is relayout QC departement. The relayout which has been done is to move $100 \%$ inspection area that itially was in the QC department, removed to the production department area, such as assembling, molding and stamping area. By removing $100 \%$ inspection area, the product handling activities are shorter because if found product reject or damaged, it can be directly repaired or returned to the department concerned. This shortens the distance and time handling process. Figure 4. illustrates lay out the current QC department, where the $100 \%$ inspection area is on the right. In Figure 5. Illustrate lay out after improvement.

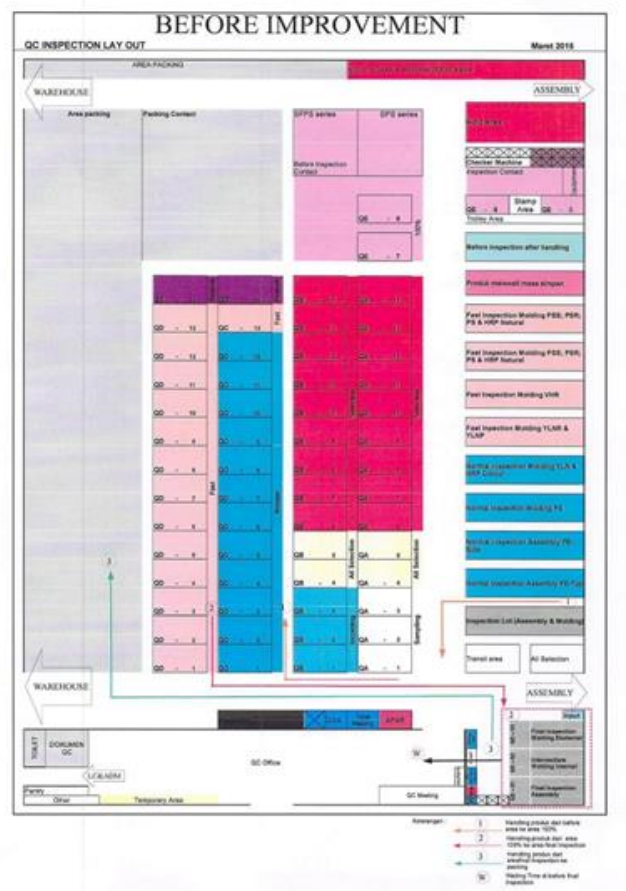

Gambar 4. Layout of the current QC department

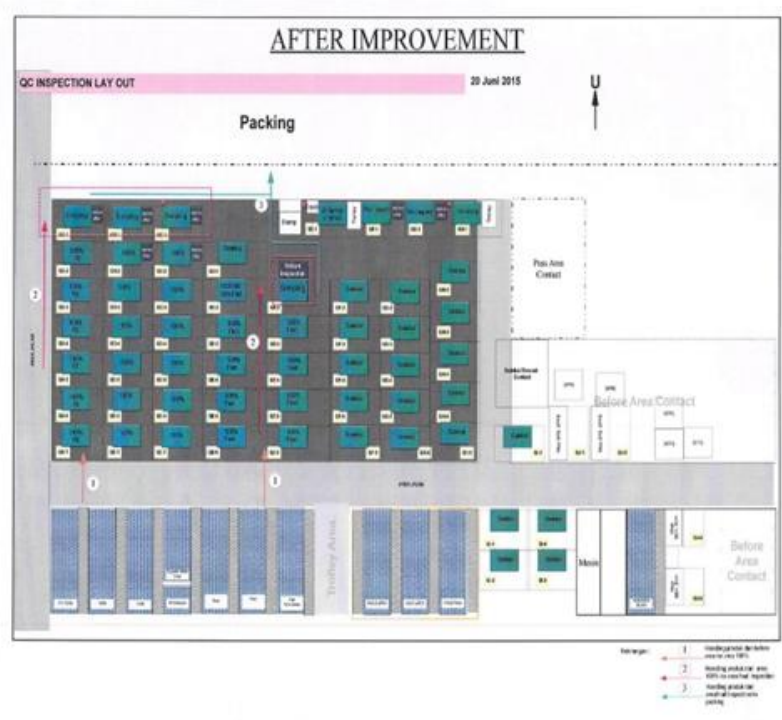

Fig 5. Layout of QC department after repair

\subsection{Improvement Analysis}

The improvement of the relayout impact on the decreasing time of handling process on other products as well. Perticularly, the assembling products that do not go through $100 \%$ inspection process where the displacement of the final inspection area also in the manufacturing area. From Figure 5.6 it can be seen that the process handling time from assembling manufacturing to QC department is 479 minutes and the waiting time in the area before inspection QC is 727 minutes.

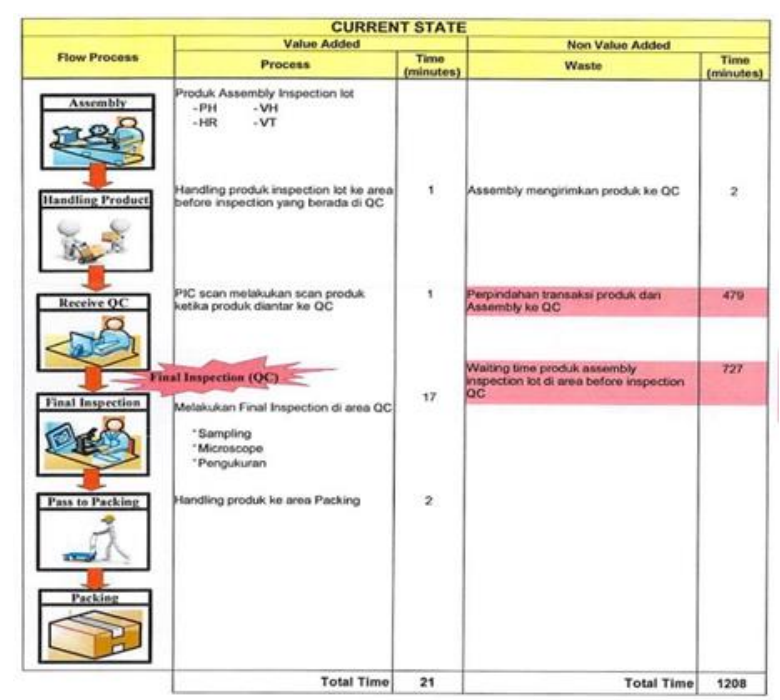




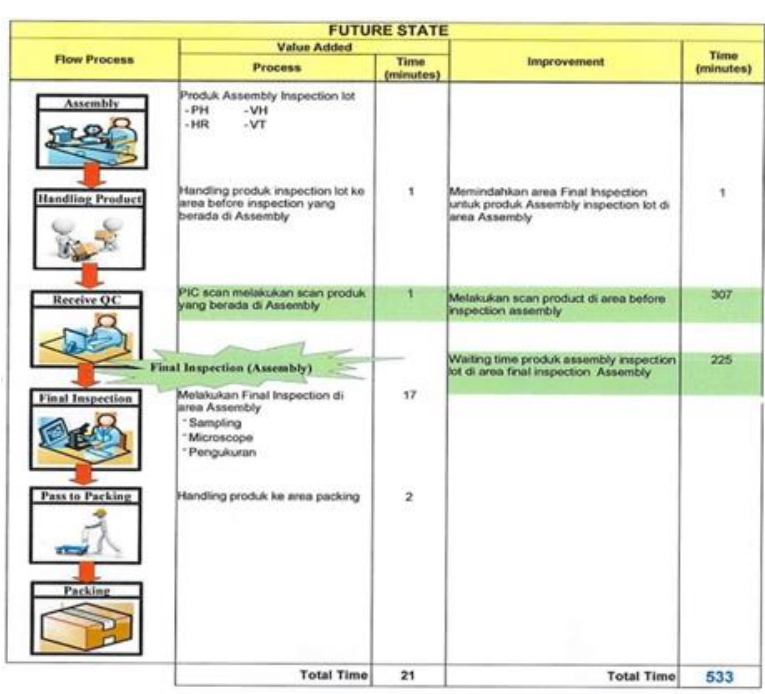

Figure 6. a. Current state assembling product b. Future state assembling products

After moving the final inspection area from QC department to manufacturing department, there is a decreasing in handling time as shown in Figure 10. below. The handling process time reduced becomes 307 minutes and the waiting time in the area before inspection QC department reduced becomes 225 minutes. For more details it can be seen in Table 6. Handling time before and after relay out the final inspection area on each item of the assembly product. The handling process time before improvement is 1208 minutes and after improvement is 533 minutes. It decrease 675 minutes or $56 \%$. Waste that occured in the handling process consists of product transfer from assembly to QC by 2 minutes, transfer from assembly to QC by 479 minutes and waiting time at before inspection area of assembly by 727 minutes.

Table 6. Time of process handling of assembly products at present

\begin{tabular}{|l|l|c|c|r|}
\hline \multicolumn{3}{|c|}{} & \multicolumn{3}{|c|}{ Current Srate } \\
\hline Series & \multicolumn{1}{|c|}{ Product Name } & Intruction & Lot No & $\begin{array}{l}\text { Waktu perpindahan produk } \\
\text { dari Assembly-QC (menit) }\end{array}$ \\
\hline HR & O4HR-4BK-P-N< & 608245 & 1 & 421 \\
\hline VH & B6P-VH (LF)(SN) & 608146 & 40 & 458 \\
\hline PH-TOP & BSB-PH-K-S (LF)(SN)(P) & 608138 & 20 & 263 \\
\hline PH-TOP & B6B-PH-K-S (LF)(SN)(P) & 607809 & 20 & 1224 \\
\hline HR & O6HR-4K-P-N< & 608181 & 1 & 30 \\
\hline \multicolumn{7}{|c|}{ Average } \\
\hline
\end{tabular}

'Total time dari waste final inspection: 1208 menit

\section{Conclusion}

Based on the collection and analysis of data obtained in this study, it can be concluded:

1. Current state mapping in Quality Control Department PT. AEMI shows that total lead time is 848 minutes with non value added activity is 778 minutes.

2. Wastes in PT.AEMI Quality Control Department for assembly product is handling process which consisting of product transfer from assembly to QC is 2 minutes, transaction from assembly to QC is 479 minutes and waiting time of assembly product at area before inspection is 727 minutes.

3. Future state mapping in Quality Control Department PT. AEMI showed that total lead time is 516,5 minutes with non value added activity is 446,5 minutes

4. Improvements made are to change the lay out of the final inspection area by moving from the QC area to the manufacture area resulting in the reduction of non-added value activity by $46 \%$.

\section{References}

[1] M. C. David and Daniel. (2011)

[2] B. J. Carroll, Lean performance ERP project management: Implementing the virtual lean enterprise, CRC Press, (2007)

[3] J. P. Womack, D. T. Jones and D. Roos, Machine that changed the world, Simon and Schuster, (1990)

[4] J. Worley and T. Doolen. Management Decision 44, 2 (2006)

[5] D. Sarkar, Lean for Service Organizations and Offices, Pearson Education India, (2008)

[6] G. Chauhan and T. Singh. Measuring Business Excellence 16, 3 (2012)

[7] J. P. Womack and D. T. Jones. Harvard business review 74, 5 (1996)

[8] B. P. Nepal, O. P. Yadav and R. Solanki. Engineering Management Journal 23, 1 (2011)

[9] P. S. Gill. Global Journal of Medical Research 12, 6 (2012) 